\title{
Por uma dogmática constitucional feminista ${ }^{1}$
}

\author{
For a feminist constitutional dogmatics
}

Por una dogmática constitucional feminista

\author{
Christine Oliveira Peter da Silva ${ }^{2}$ \\ Centro Universitário de Brasília - UniCEUB (Brasília, DF, Brasil) \\ ORCID: https://orcid.org/0000-0003-2572-0509 \\ E-mail:christinepeter@uol.com.br
}

\section{Resuimo}

O objeto do trabalho é a dogmática constitucional feminista. Não obstante a expressão "constitucionalismo feminista" já faça parte do léxico acadêmico internacional, ainda não há uma doutrina brasileira sistematizada sobre as suas diversas perspectivas, de forma que o presente trabalho objetiva apresentar a perspectiva dogmática do constitucionalismo feminista brasileiro. Por dogmática jurídica compreende-se a linha de pensamento voltada para a decidibilidade normativa dos conflitos, sendo a dogmática constitucional feminista uma proposta de releitura da dogmática constitucional pela voz, intelectualidade e experiência das mulheres. A partir de revisão bibliográfica e pesquisa documental, apresentam-se os pressupostos doutrinários e as normas constitucionais positivadas, que garantem direitos fundamentais para as mulheres e minorias de gênero, bem como os precedentes constitucionais do Supremo Tribunal Federal que evidenciam, nos anos de 2019 e 2020, discursos e argumentos com influência das premissas da dogmática constitucional feminista.

\section{Palavras-chave}

Direito constitucional; Constitucionalismo feminista; Dogmática constitucional; Direitos fundamentais das mulheres.

\footnotetext{
${ }^{1}$ PETER DA SILVA, Christine Oliveira. Por uma dogmática constitucional feminista. Suprema: revista de estudos constitucionais, Brasília, v. 1, n. 2, p. 151-189, jul./dez. 2021.

2 Professora titular do Centro Universitário de Brasília (UniCEUB). Doutora em Direito, Estado e Constituição pela Universidade de Brasília (UnB). Currículo Lattes: http://lattes.cnpq.br/4549632872816353.
} 


\title{
Sumário
}

1. Introdução. 2. Premissas dogmático-doutrinárias do constitucionalismo feminista. 2.1 Igualdade. 2.2 Dinâmica centro-periferia. 2.3 Releitura da doutrina constitucional clássica. 2.4 Perspectivas subjetiva e objetiva dos direitos fundamentais. 2.5 Perspectivas global e comparativa. 2.6 Perspectiva interseccional. 3. Premissas dogmático-normativas do constitucionalismo feminista. 4. Premissas dogmático-jurisprudenciais do constitucionalismo feminista. 5. Conclusão.

\begin{abstract}
The object of the present work is feminist constitutional dogmatics. Notwithstanding the expression 'feminist constitutionalism' is already part of the international academic lexicon, there is still no systematized brazilian doctrine on its premises, so that the present work aims to present the dogmatic contributions of brazilian feminist constitutionalism. Dogmatics is understood as a line of thought aimed at the normative decision-making of conflicts, so that feminist constitutional dogmatics is a proposal to re-read the contributions of classical constitutional dogmatics through women's voice, intellectuality and experience. Based on bibliographic review and documentary research, doctrinal premises and positive norms of the 1988 brazilian Constitution are presented as evidences of feminist constitutional dogmatics. Finally, the constitutional precedents of the Federal Supreme Court are also recorded and analyzed, in the years 2019 and 2020, looking for speeches and arguments of feminist constitutional dogmatics.
\end{abstract}

\section{Keywords}

Constitutional Law; Feminist Constitutionalism; Constitutional Dogmatics; Women's constitutional rights.

\section{Contents}

1. Introduction. 2. Dogmatic-doctrinal premises of feminist constitutionalism. 2.1 Equality. 2.2 Center-periphery dynamics. 2.3 Rereading the classic constitutional doctrine. 2.4 Subjective and objective perspectives of fundamental rights. 2.5 Global and comparative perspectives. 2.6 Intersectional perspective. 3. Dogmatic-normative premises of feminist constitutionalism. 4. Dogmaticjurisprudential premises of feminist constitutionalism. 5. Conclusion. 


\section{Resumen}

El objeto del trabajo es la dogmática constitucional feminista. A pesar de que la expresión 'constitucionalismo feminista' ya forma parte del léxico académico internacional, aún no existe una doctrina brasileña sistematizada sobre sus diferentes perspectivas, siendo el objectivo de este trabajo presentar los aportes dogmáticos del constitucionalismo feminista brasileño. La dogmática se entiende como una línea de pensamiento centrada en la toma de decisiones normativas de los conflictos, siendo la dogmática constitucional feminista una propuesta para releer los aportes de la dogmática constitucional clásica a través de la voz, la intelectualidad y la experiencia de las mujeres. Con base en la revisión bibliográfica y la investigación documental, se presentan los supuestos doctrinales y las normas positivas de la Constitución de 1988, que garantizan los derechos fundamentales de las mujeres y minorías. Finalmente, también se registran y analizan los precedentes constitucionales del Supremo Tribunal Federal que evidencian, en los años 2019 y 2020, discursos y argumentos de la dogmática constitucional feminista.

\section{Palabras clave}

Derecho constitucional; Constitucionalismo feminista; Dogmática constitucional; Derechos fundamentales de la mujer.

\section{Índice}

1. Introducción. 2. Premisas dogmático-doctrinales del constitucionalismo feminista. 2.1 Igualdad. 2.2 Dinámica centro-periferia. 2.3 Releyendo la doctrina constitucional clásica. 2.4 Perspectivas subjetivas y objetivas de los derechos fundamentales. 2.5 Perspectivas globales y comparativas. 2.6 Perspectiva interseccional. 3. Premisas dogmático-normativas del constitucionalismo feminista. 4. Premisas dogmático-jurisprudenciales del constitucionalismo feminista. 5. Conclusión. 6. Referencias. 


\section{Introdução}

O presente trabalho tem por objeto a perspectiva dogmática do constitucionalismo feminista, cuja expressão, ainda em construção pela doutrina constitucional mundial, está inserida no âmbito do constitucionalismo contemporâneo como um vetor jurídico do exercício do poder constituinte originário, derivado e difuso, no contexto de uma nova era democrática (RUBIO-MARÍN; IRVING, 2019).

Por constitucionalismo contemporâneo entenda-se o movimento histórico-político e cultural que, sobretudo a partir da segunda metade do século 18 , refundou os sistemas tradicionais de domínio político, fazendo surgir um modelo alicerçado em três princípios: submissão da política ao direito; descentralização das funções de poder e garantia jurídico-normativa de direitos fundamentais (CANOTILHO, 2003, p. 51-52).

Muito embora a expressão "constitucionalismo feminista" já faça parte do léxico acadêmico internacional (BAINES; BARAK-EREZ; KAHANA, 2012), ainda não se tem uma doutrina brasileira sistematizada sobre as suas perspectivas históricas, teórico-epistemológicas, metodológicas nem dogmáticas. O estudo da perspectiva dogmática é a lacuna que se pretende preencher com o presente trabalho.

O constitucionalismo feminista é uma releitura do constitucionalismo contemporâneo pela voz de constitucionalistas brasileiras e estrangeiras que defendem, sob a perspectiva metodológica, o gênero como um método integral que direciona a hermenêutica das normas constitucionais para aspectos que o direito constitucional contemporâneo sombreia ou, até mesmo, exclui e, não raras vezes, marginaliza (BAINES; BARAK-EREZ; KAHANA, 2012; PETER DA SILVA; GOMIDE, 2020; SILVA; WRIGHT, 2015).

Por se tratar de um movimento complexo, tal qual o próprio constitucionalismo contemporâneo, o constitucionalismo feminista propõe seu desenvolvimento em múltiplas perspectivas, entre as quais estão em evidência: 
a perspectiva histórica ${ }^{3}$; a perspectiva teórico-epistemológica ${ }^{4}$; a perspectiva metodológica ${ }^{5}$; e a perspectiva dogmática ${ }^{6}$.

Sob a perspectiva dogmática, escolhida para a abordagem do presente trabalho, almeja-se apresentar as premissas doutrinárias, normativas e jurisprudenciais oferecidas pelo constitucionalismo feminista às decisões constitucionais do Estado Democrático de Direito brasileiro. Importante registrar que o constitucionalismo feminista propõe uma releitura do constitucionalismo contemporâneo em seus múltiplos aspectos, mas o presente trabalho se restringe à perspectiva dogmática do constitucionalismo feminista, o que implica reconhecer que aqui se tratará apenas das abordagens doutrinárias, normativo-positivadas e jurisprudenciais voltadas à decidibilidade das questões constitucionais postas.

A denúncia de que as premissas das diversas perspectivas do constitucionalismo contemporâneo clássico revelam-se inadequadas e insuficientes para o século 21, porque coloca apenas uma parcela da humanidade como centro e referência de universalidade, consequência irrefutável da chamada masculinidade hegemônica (CONNELL; MESSERSCHMIDT, 2013), já está posta.

Porém é, ainda, urgente a conscientização das cidadãs e dos cidadãos do mundo inteiro, em geral, e dos brasileiros, em particular, de que a igualdade, como princípio constitucional fundamental estruturante da nação constituída, somente poderá ser concretizada se diante do inexorável respeito e consideração (DWORKIN, 2000, p. 293) ao outro e ao diferente.

Autoras como Donna Greschner (1986), Ruth Rubio-Marin (2010), Beverley Baines, Daphne Barak-Erez e Tsvi Kahana (2012) e Nilda Garay Montanez (2014)

\footnotetext{
${ }^{3}$ Na perspectiva histórica, o constitucionalismo feminista propõe estudos e pesquisas das fontes históricas primárias do constitucionalismo contemporâneo, com especial atenção para o lugar e o papel das mulheres nos eventos, fatos e atos históricos relevantes para o movimento.

${ }^{4}$ Na perspectiva teórico-epistemológica, o constitucionalismo feminista indica reflexões e proposições ideológicas que podem impulsionar as escolhas, ações e repercussões protagonizadas pelos agentes políticos, públicos e da sociedade civil comprometidos com o movimento.

${ }_{5}$ Na perspectiva metodológica, o constitucionalismo feminista sugere esquemas metodológicos, especialmente de matriz hermenêutica, para permitir o controle e a revisão das escolhas, ações e repercussões do movimento nas instituições e na própria sociedade.

${ }^{6}$ Na perspectiva dogmática, o constitucionalismo feminista oferece os instrumentos disponíveis em um determinado ordenamento jurídico-constitucional - doutrina especializada, normas jurídicas positivadas e jurisprudência para fundamentar decisões constitucionais legitimadas e racionalmente compartilhadas pela comunidade nacional subjacente.
} 
sustentam, insistentemente, a proposta de uma teoria constitucional feminista, a qual desafia, constrange e fornece os primeiros aportes científicos para a dogmática constitucional feminista, tema das reflexões aqui apresentadas.

Confrontando a pergunta feita por Donna Greschner (1986, p. 20), ao questionar se as Constituições também são feitas para as mulheres, é possível perceber, sem muito esforço investigativo, que a resposta afirmativa, automática e solene vai perdendo a sua força à medida que os dados de direito constitucional comparado anunciam a insatisfatória e, persistentemente, ínfima participação das mulheres nos processos constituintes, nos parlamentos nacionais e nas supremas cortes dos diferentes períodos históricos de diversos países, incluindo o Brasil. ${ }^{7}$

É necessário conscientizar-se de que a Constituição de cada país é também a Constituição constituída, criticada e vivida por mulheres. Tal assertiva interpela ativistas, advogadas, juízas e acadêmicas para jogar luzes sobre o que está em jogo: é necessário questionar não apenas se as Constituições são também para as mulheres, mas, sobretudo, quando e como garantir que as Constituições, como normas jurídicas reais e efetivas, reconheçam e promovam os seus direitos fundamentais.

O objetivo das reflexões do presente trabalho é apresentar o tripé de sustentação dogmática do constitucionalismo feminista. Para tanto serão registradas: i) a doutrina especializada sobre os pressupostos do constitucionalismo feminista; ii) as normas constitucionais positivadas na Constituição de 1988 garantidoras de direitos fundamentais das mulheres e minorias; e iii) a jurisprudência do Supremo Tribunal Federal concretizadora de direitos fundamentais das mulheres e das minorias relacionadas.

Com a intenção de apresentar as premissas dogmático-doutrinárias do constitucionalismo feminista, vai-se fazer uma revisão bibliográfica das autoras e dos autores que, de forma especializada e orientada ao tema, oferecem suporte doutrinário aos agentes públicos e políticos que decidem questões constitucionais. Por meio de pesquisa documental, serão registradas as principais normas constitucionais positivadas, na Constituição da República brasileira de 1988, sobre direitos fundamentais das mulheres e minorias relacionadas, bem como 
a jurisprudência selecionada do Supremo Tribunal Federal sobre os direitos fundamentais das mulheres e minorias de gênero.

A pesquisa de jurisprudência será resultado de busca no sítio do Supremo Tribunal Federal, disponível na rede mundial de computadores, utilizando-se a expressão "mulher" e restringindo o período de julgamento dos processos aos anos de 2019 e 2020. Serão também aplicados os filtros de exclusão, com a expressão "não", às classes processuais habeas corpus, recurso em habeas corpus, mandado de segurança e reclamação.

Considerando a dogmática como o pensamento voltado para a decidibilidade normativa dos conflitos (FERRAZ JÚNIOR, 1998, p. 157), a dogmática constitucional feminista será aqui proposta como uma releitura da dogmática constitucional, no plano de sua doutrina, legislação e jurisprudência, a partir do ponto de vista e das experiências constitucionais das mulheres, em direção à máxima potencialidade da concretização dos seus direitos fundamentais expressos na Constituição brasileira de 1988.

\section{Premissas dogmático-doutrinárias do constituciona- lismo feminista}

O constitucionalismo feminista, como meio e possibilidade da hermenêutica feminista de compreender e interpretar o direito e a Constituição, do lugar de fala da mulher, em toda a sua mais ampla magnitude, consiste em: identificar e desafiar os elementos da dogmática jurídica que discriminam por gênero, raciocinar a partir de um referencial teórico segundo o qual as normas jurídicas e constitucionais são respostas pragmáticas para dilemas concretos das mulheres reais, mais do que escolhas estáticas entre sujeitos opostos ou pensamentos divergentes, bem como aumentar as possibilidades de colaboração entre diversas visões e experiências vivenciadas, tanto por homens quanto por mulheres engajadas e comprometidas com esse caminho (BARTLETT, 1990, p. 833).

Não há, portanto, pré-compreensões fixas e imutáveis nesse universo em movimento. A igualdade, como meta de equitativa consideração e respeito (DWORKIN, 2000, p. 293) em múltiplas direções, com inexorável tolerância às diferenças, passa a ser a condição de possibilidade de todas as formas de pensar e de agir, de ser e de estar no mundo, mundo este expandido para além 
dos binarismos do sexo biológico (homem e mulher), de gênero (masculino e feminino) ou da orientação sexual (heterossexual e homossexual).

É da tensão e do pluralismo que emergem as condições de construção e descoberta, sempre coletiva, dos aportes históricos, teórico-epistemológicos, metodológicos e dogmáticos do constitucionalismo feminista. Assim sendo, serão apresentadas, numa perspectiva crítica e criativa, as premissas dogmático-doutrinárias do constitucionalismo feminista tais quais foram registradas pelas professoras Berveley Baines, Daphne Barak-Erez e Tsvi Kahana, na introdução da obra Feminist Constitutionalism: global perspectives (2012, p. 2-4).

\subsection{Igualdade}

O primeiro fundamento, pilar essencial, do constitucionalismo feminista é a igualdade, em sua mais ampla e multifacetada acepção. A ideia de igualdade, para o constitucionalismo feminista, é a sua principal e mais evidente premissa dogmático-doutrinária, de forma que, tanto na perspectiva do direito subjetivo à isonomia quanto na perspectiva das políticas públicas que buscam a concretização da igualdade, é preciso considerá-la em todas as decisões informadas pela dogmática constitucional feminista.

Para mulheres, assim como para outras minorias excluídas das decisões de poder, a luta pela igualdade formal é um primeiro e importante passo rumo ao seu reconhecimento como cidadãs e cidadãos das nações em que vivem. $\mathrm{O}$ Estado Democrático de Direito, nesse particular, tem importante função, pois, ao reconhecer, na Constituição e nas leis, a igualdade formal entre homens e mulheres, já catalisa e potencializa a segunda aspiração, que é a igualdade material ${ }^{8}$, meta que constitui e é constituída pela ideia de democracia paritária ${ }^{9}$.

\footnotetext{
${ }^{8}$ Sobre a diferença entre igualdade material e formal importante relembrar aqui as lições de Flávia Piovesan sobre as três vertentes, no que tange à concepção da igualdade: “[...] a. igualdade formal, reduzida à fórmula 'todos são iguais perante a lei’ (que no seu tempo foi crucial para a abolição de privilégios); b. igualdade material, correspondente ao ideal de justiça social e distributiva (igualdade orientada pelo critério socioeconômico); e c. igualdade material, correspondente ao ideal de justiça como reconhecimento de identidades (igualdade orientada pelos critérios gênero, orientação sexual, idade, raça, etnia e demais critérios).” (PIOVESAN, 2005).

9 Em 2015, na cidade do Panamá, foi aprovado, pela Assembleia Geral do Parlatino - Parlamento Latino-americano e do Caribe, o marco normativo para consolidar a democracia paritária, documento normativo cujo objetivo é ser referência para "a implementação de reformas institucionais e políticas que promovam e assegurem a igualdade substantiva entre homens e mulheres em todas as esferas de tomada de decisão." (ONU MULHERES, 2018).
} 
A igualdade material entre os cidadãos e as cidadãs de uma nação tem consequências para toda a sociedade, pois, tanto no plano dos direitos individuais quanto no âmbito dos direitos coletivos e das políticas públicas, a igualdade de gênero apresenta-se como fator decisivo para o desenvolvimento sustentável, tanto sob o ponto de vista econômico quanto sociocultural (BORTOLUZZO; MATAVELLI; MADALOZZO, 2016).

A igualdade material, como pressuposto dogmático do constitucionalismo feminista, apresenta-se como vetor hermenêutico para todas as decisões de poder, de forma que vincula os membros e órgãos de poder, em todas as suas esferas territoriais e funcionais. Isso implica reforçar que não se trata apenas de reconhecer a igualdade como uma ideologia ou como uma expressão retórica presente nos discursos constitucionais das arenas políticas.

A igualdade material deve ser aferível na experiência humana, apresentando-se, nesse contexto, como premissa inexorável de todas as reflexões, todas as ações, todos os atos e eventos relacionados às decisões de poder. $\mathrm{O}$ modelo político chamado Estado Democrático de Direito passa, assim, a ser informado, em primeiro plano e preferencialmente, pela igualdade. Desse modo, a igualdade deixa de ser uma ideia ou um valor e passa a traduzir-se em direitos e deveres jurídicos, atos e eventos políticos, decisões judiciais e administrativas, contratos e atos da vida privada. A igualdade deixa o lugar idealizado da vontade e passa a ser uma realidade experimentada pelos cidadãos e cidadãs brasileiras.

A igualdade material do constitucionalismo feminista também é sinônimo de igualdade de gênero, que constitui uma ação multidirecional e multifuncional. Essa ação não se reduz a posturas positivas ou negativas, nem ativas ou passivas, por parte dos agentes políticos, públicos e privados, mas conflui em um conjunto sistêmico e estruturado de esforços do Estado Democrático de Direito em busca de uma sociedade mais justa e mais equitativa, mais tolerante e mais inclusiva, porque naturalmente plural.

\subsection{Dinâmica centro-periferia}

Um segundo pilar do constitucionalismo feminista, pressuposto fundamental, portanto, da dogmática constitucional feminista, é a dinâmica centro-periferia a impulsionar os órgãos de poder, seja no ambiente público, 
seja no privado, a acolher como problemas essenciais aqueles que dizem respeito à vida das mulheres, em sua mais ampla dimensão.

Imagina-se, de antemão, que o constitucionalismo feminista seja guiado pelos pressupostos epistemológicos da isonomia e da inclusão, aptos a lidar com uma dogmática constitucional axiologicamente comprometida com o princípio da igualdade, como respeito ao outro e ao diferente, bem como com uma metodologia que aproxima a mulher, em seu sentido mais amplo, do exercício pleno de sua cidadania constitucional.

Nesse particular, a proposta é deslocar os temas considerados pouco importantes para o direito constitucional, porque confinados junto com as mulheres aos muros dos espaços domésticos e privados, para o centro dos debates constitucionais mais relevantes. Direitos fundamentais relacionados à saúde da mulher, ao trabalho doméstico, ao mercado de trabalho relacionado ao cuidado, aos direitos reprodutivos, ao planejamento familiar, aos cuidados com a infância e a maternidade, aos direitos sociais e assistenciais, à violência doméstica, à violência obstétrica, entre outros, devem ser pautados na agenda das decisões constitucionais da nação.

Os grandes temas constitucionais que interessam às maiorias e/ou minorias hegemônicas, os quais geralmente ganham destaque nas pautas do constitucionalismo contemporâneo, devem ser discutidos ao lado dos temas que interessam às minorias e/ ou às maiorias não hegemônicas, como é o caso das mulheres. Os temas da agenda das mulheres devem ter os mesmos espaços de debate e deliberação nas instituições públicas e privadas da nação.

A partir da dinâmica centro-periferia e periferia-centro, os temas constitucionais relevantes serão tão múltiplos quanto plurais, não devendo ser classificados e escolhidos de acordo com o padrão de poder hegemônico, em determinado tempo e espaço, pelos inquilinos dos espaços de poder. A força das democracias é a igualdade de chances para as deliberações políticas, de forma que não é apenas simbólica a luta para a ocupação de cadeiras nos órgãos de poder, especialmente aqueles de cúpula, sendo importante considerar que, também nesses espaços, há muita violência e abuso de poder (COELHO, 2020, p. 167-209).

Os debates constitucionais de uma nação devem ter temas que interessem às mulheres, temas que digam com suas vidas, suas aspirações, suas histórias. Os estranhamentos em relação a tais temas devem ser considerados tentativas 
subversivas de capturas antidemocráticas dos lugares reais e simbólicos de poder. O constitucionalismo feminista e a dogmática constitucional respectiva exigem postura inclusiva quanto aos temas de interesses das mulheres nos espaços de poder.

\subsection{Releitura da doutrina constitucional clássica}

O terceiro fundamento teórico da dogmática constitucional feminista é a crítica aos paradigmas constitucionais clássicos pelo olhar, pela inteligência e reflexão das mulheres, numa tentativa de reescrever os capítulos do direito constitucional pela perspectiva daquelas que foram colocadas à margem desse debate em sua versão original.

A crítica é intrínseca aos movimentos revolucionários, que não se contentam com o status quo e se dispõem a pensar e agir a partir de outras premissas e diferentes métodos. Essa é a proposta do terceiro pilar da dogmática constitucional feminista: reler tudo o quanto o direito constitucional constituiu pelas lentes próprias, ou seja, no âmbito feminino, pelas lentes das mulheres.

As categorias e os princípios constitucionais devem ser repensados, bem como seus sentidos e significados, a partir dos lugares de vivências e experiências das mulheres. E um primeiro deslocamento proposto nesse sentido é a análise crítica da dicotomia entre público e privado, considerando aqui público e privado como os espaços de ação e expressão das mulheres, que, antes confinadas em suas casas e igrejas, passam a ocupar, também, a liderança política em suas comunidades e cargos nas instituições públicas do Estado Democrático de Direito (BAINES; BARAK-EREZ; KAHANA, 2012, p. 2-3). Também é preciso pensar sobre os conceitos de justiça, dignidade, cidadania, moralidade e outros que foram, predominantemente, construídos por homens.

Nesse ponto, há propostas concretas em andamento sobre releituras de obras clássicas do direito constitucional e de precedentes da jurisprudência constitucional de cada país por mulheres (STANCHI; BERGER; CRAWFORD; 2016). Trata-se de dar voz e chamar a atenção para a ausência da voz e da opinião das mulheres nos lugares de poder, na doutrina dominante, na interpretação das normas constitucionais de cada país.

É preciso rever os pressupostos teóricos e filosóficos do direito constitucional a partir das vozes e dos pensamentos das mulheres, pois elas foram, 
e ainda são, sujeitos e cidadãs excluídas dos processos constitucionais formais, seja no âmbito da constituição das normas jurídicas, incluindo a fundamental, seja no âmbito de sua interpretação e concretização, em geral capturada por membros masculinos dos governos e das Supremas Cortes, no mundo inteiro.

\subsection{Perspectivas subjetiva e objetiva dos direitos fundamentais}

É uma quarta premissa da dogmática constitucional feminista considerar a dupla perspectiva dos direitos fundamentais: direitos subjetivos e políticas públicas. Segundo as professoras Berveley Baines, Daphne Barak-Erez e Tsvi Kahana (2012, p. 3), é preciso enfrentar a tentação de associar as questões de gênero para o direito constitucional com a agenda da luta ativista por direitos fundamentais subjetivos, individuais ou coletivos, de igualdade de gênero, sendo imprescindível envolver as instituições nesse debate.

A formulação de políticas públicas é fundamental para que as lutas ativistas possam surtir efeitos mais amplos e mais longevos. Não se pode pensar apenas em direitos subjetivos, quando se está a tratar de direitos fundamentais que concretizam a igualdade, especialmente, a de gênero. Ao envolver instituições e criar institutos que promovam a inclusão das minorias e/ou maiorias não hegemônicas nos espaços de poder, é menor o risco de retrocessos e mais sustentável a vitória de toda a sociedade.

O constitucionalismo feminista deve ter como missão a institucionalização dos direitos fundamentais das mulheres, tanto na perspectiva de direitos subjetivos, individuais e coletivos quanto de políticas públicas, cujos efeitos dirigente, irradiante e horizontal vincularão todas as autoridades públicas e privadas da nação (PETER DA SILVA, 2015, p. 72-76).

No que diz respeito à eficácia irradiante, pode-se afirmar que ela fornece impulsos e diretrizes para a aplicação e interpretação das leis infraconstitucionais informadas pelos princípios constitucionais fundamentais, numa verdadeira interpretação conforme, que prestigia a igualdade de gênero como vetor da interpretação de todas as normas do ordenamento jurídico.

Associada à eficácia irradiante está a eficácia horizontal dos direitos fundamentais, ou seja, a força vinculante da Constituição também para a esfera 
privada. A partir dessa ideia, os princípios constitucionais fundamentais, entre os quais está o da igualdade de gênero, irradiam seus efeitos para as relações entre particulares.

Por fim, um terceiro e último desdobramento da perspectiva objetiva dos direitos fundamentais é a eficácia dirigente das Constituições, segundo a qual os princípios fundamentais da Constituição obrigam os agentes públicos e políticos, em um compromisso inabalável, a considerar e respeitar a Constituição em todos os seus atos de poder. Nesse ponto, exigir dos agentes de poder o respeito à igualdade de gênero passa a ser mais natural.

\subsection{Perspectivas global e comparativa}

O constitucionalismo feminista é um movimento acadêmico que só acontece em rede e no coletivo, ou seja, nas perspectivas global e comparativa. Assim, é imprescindível conhecer as realidades das Constituições, da produção acadêmica e da jurisprudência das diferentes nações do mundo, para que se consiga uma base epistemológica e metodológica sustentável para o constitucionalismo feminista.

Imprescindível, nesse contexto, a ideia de Estado constitucional cooperativo, que se apresenta como aquele que vive de redes de cooperação econômica, social, humanitária e antropológica, no qual existe uma real necessidade de desenvolvimento de uma cultura cooperativa, no sentido da internacionalização da sociedade, da rede de dados, da esfera pública mundial e de legitimação da política externa (HÄBERLE, 2003, p. 68-69).

Como o propósito do constitucionalismo feminista é refundar o constitucionalismo clássico para nele incluir vozes, pensamentos, vivências e experiências de todos e todas que foram alijados do processo inaugural desse movimento, ter como premissas as perspectivas global e comparativa é considerar as metodologias abertas, plurais, inclusivas e sustentáveis como premissas dos estudos do constitucionalismo feminista.

As redes de cooperação e as alianças para aprendizados compartilhados fazem da reciprocidade um vetor importante da dogmática constitucional feminista. Não há como estudar o direito constitucional feminista sem o domínio das técnicas de comparação (PETER DA SILVA, 2014, p.73-126) e sem as redes e 
alianças que se formam em perspectiva global e comparativista para problemas constitucionais comuns.

Não se pode deixar de registrar que as mulheres são excluídas dos espaços de poder no mundo inteiro, mesmo naqueles países que são considerados os mais avançados. No que diz respeito à igualdade de gênero, em áreas específicas, como a representação política, por exemplo, as mulheres travam suas lutas históricas para a redução de todas as outras formas de desigualdades e discriminações.

A utilização do método comparativo em direito constitucional não é uma unanimidade, gerando muitas controvérsias teóricas e pragmáticas, por estarem ainda em construção as diversas possibilidades metodológicas para sua implementação prática. Estudam-se, nesse contexto, os "transplantes constitucionais", os "empréstimos constitucionais", a "fertilização cruzada", a "migração de ideias constitucionais” e os "diálogos transjudiciais” (PETER DA SILVA, 2014, p. 99-119).

A tarefa de estudar o direito constitucional por meio da metodologia comparativa exige esforço epistemológico, teórico e dogmático por parte dos juristas, e, por isso, a dogmática constitucional feminista também está desafiada neste ponto. Trata-se de uma premissa dos estudos constitucionais feministas incluir a perspectiva global e comparativa em suas investigações, porém o caminho ainda não está trilhado e o instrumental não está consolidado, mas alguns avanços doutrinários e jurisprudenciais podem ser encontrados em sede doutrinária (BAINES; BARAK-EREZ; KAHANA, 2012).

\subsection{Perspectiva interseccional}

A sexta premissa da dogmática constitucional feminista é a integração das teorias da diversidade, ou seja, a consideração da perspectiva interseccional como fundamento da doutrina constitucional feminista.

Nessa perspectiva, é importante fazer um registro inicial relevante: o constitucionalismo clássico descortinou-se, ao longo dos dois últimos séculos, como um movimento que promoveu ou tolerou diversas e sérias exclusões. Apesar de o motivo condutor do constitucionalismo clássico sempre ter sido o reconhecimento de direitos fundamentais e a organização do poder do Estado Democrático de Direito em benefício da cidadania, o que se registra, na história, 
numa visão contextual, são discursos e ações de exclusões persistentes. Nesse particular, potentes as palavras de Bell Hooks:

Imagine viver em um mundo onde não há dominação, em que mulheres e homens não são parecidos nem mesmo sempre iguais, mas em que a noção de mutualidade é o ethos que determina nossa interação. Imagine viver em um mundo onde todos nós podemos ser quem somos, um mundo de paz e possibilidades. Uma revolução feminista sozinha não criará esse mundo; precisamos acabar com o racismo, o elitismo, o imperialismo (HOOKS, 2020, p. 15).

A primeira e mais evidente exclusão percebida e denunciada, há mais de um século, pelos movimentos feministas, numa primeira onda conhecida como sufragista (GONÇALVES; PINTO, 2011), é a exclusão das mulheres dos direitos civis e políticos. As mulheres e cidadãs não foram destinatárias das conquistas das revoluções liberais do final do século 18 (DALLARI, 2016), o que justifica a sua luta, até os dias atuais, pelos direitos fundamentais que sempre foram reconhecidos aos homens.

E, não se pode deixar de registrar que, junto com as mulheres, tudo o que diz respeito ao feminino também foi marginalizado e confinado aos ambientes domésticos e privados, excluído, portanto, da arena pública e política. Assim, as exclusões do constitucionalismo clássico também se dirigiam ao gênero feminino e à orientação sexual diversa da heterogâmica patriarcal.

Uma segunda exclusão diz respeito à raça, ou seja, o constitucionalismo clássico, especialmente aquele forjado no século 19, tolerou práticas racistas institucionalizadas. As consequências do racismo e das diferenciações opressivas relacionadas à cor da pele, à origem étnica ou à opção cultural-religiosa sempre estiveram presentes na sociedade, sendo, às vezes de forma sutil, outras de forma explícita, estimuladas e/ou toleradas pelas práticas constitucionais institucionalizadas.

A terceira exclusão está relacionada à classe social, sendo muitas vezes denunciada pelos movimentos antielitistas. O desenvolvimento e o progresso prometidos pelos movimentos liberais encontraram resistência, já no século 19, pela voz e força daqueles que se sentiam explorados na relação capital-trabalho. Não se pode observar o constitucionalismo clássico nem a ascensão de um modelo de Estado Social de Direito, especialmente a partir da segunda década 
do século 20, sem atentar para as lutas que foram travadas entre trabalhadores e donos do capital.

Uma pergunta importante que surge, nesse contexto, é se existe feminismo sem luta de classe. A resposta é complexa, mas se inclina para a direção positiva, considerando que as teorias feministas desbordaram do marxismo e também foram forjadas a partir de outros paradigmas como o existencialismo (BEAUVOIR, 2000), a psicanálise (BRENNAN, 1992) e o pós-estruturalismo (BUTLER, 2003), para mencionar os mais conhecidos.

A quarta exclusão está diretamente vinculada à nacionalidade e formação cultural, ou seja, à hegemonia econômica e cultural da nação onde o indivíduo nasce e é educado. O imperialismo e o colonialismo são as expressões concretas desse tipo de exclusão, a qual força nações e comunidades culturais inteiras a se submeterem às vontades e imposições do colonizador.

Partindo de uma compreensão de constitucionalismo que relaciona humanismo e feminismo como movimentos coincidentes, em suas origens, é preciso dizer que eles são abastecidos pelas mesmas fontes históricas e culturais, bem como são desafiados pelos mesmos detratores. Sexismo, racismo, elitismo e imperialismo/colonialismo são formas de violência e opressão contra o outro e em desrespeito ao diferente.

Muito embora a pauta humanista possa ser considerada mais abrangente do que a pauta feminista, em termos mais estreitos de pontuação histórica, a luta dos movimentos feministas, abolicionistas, igualitaristas e decolonialistas, nos últimos dois séculos, atesta muito mais interseções do que oposições, muito mais perpendiculares do que paralelos.

Humanismo e feminismo encontram-se e, na dogmática constitucional feminista, interpelam à ação de todos e todas para o que parece óbvio, mas não o é: direitos das mulheres são direitos humanos (MACKINNON, 2006) e o feminismo não beneficia apenas as mulheres, mas toda a humanidade (HOOKS, 2020). 


\section{Premissas dogmático-normativas do constitucionalismo feminista}

A Constituição brasileira não é vista como uma norma jurídica material e especificamente destinada às mulheres. Talvez, por isso, não se estabeleça, de forma explícita, uma conexão, nos estudos brasileiros, entre as perspectivas do movimento constitucionalista, as teorias da Constituição e as teorias feministas.

A manifesta ausência da opinião das mulheres acerca dos desafios constitucionais enfrentados pelo Brasil, de um modo geral, e pelo Supremo Tribunal Federal, em particular, é o que motiva o constitucionalismo feminista como um movimento acadêmico, além de social, político e cultural.

É preciso chamar a atenção para o que há de feminino, em seu mais amplo sentido, na Constituição e no constitucionalismo brasileiro, mas também para o que nunca foi dito e percebido pelas mulheres sobre a Constituição, sobre as normas constitucionais e sobre a concretização dos direitos fundamentais, especialmente aqueles a elas especificamente destinados (PETER DA SILVA; ROSA, 2019).

Firme na promessa constitucional de 1988 de que o Estado Democrático de Direito também constitui o direito fundamental à igualdade de gênero como um de seus pilares, é preciso ter em mente as lições da Professora Vera Karam de Chueiri (2013, p. 35), quando afirma que a Constituição e a democracia, como promessas, “[...] contêm a radicalidade que abala os horizontes estáveis das nossas expectativas, transgredindo o possível e o concebível, indo além do que é visível e previsível e que não é propriedade de algum povo escolhido, mas de todos. Assim, é desde a promessa que o real se instala.".

Esse é o desafio aqui proposto, buscar, nas normas constitucionais positivadas na Constituição de 1988, as ferramentas jurídicas necessárias para a construção de um Estado Democrático de Direito que suporte uma Constituição radical e plural, que seja também de e para mulheres.

É preciso registrar que a expressão "mulher" está grafada doze vezes, expressamente, na Constituição vigente no Brasil. Sendo a Constituição brasileira que mais contém o termo "mulher" (PETER DA SILVA; ROSA, 2019) expressamente grafado em suas normas, não se pode olvidar que a Constituição da República brasileira de 1988 é fruto de intensa e bem sucedida participação 
das mulheres no processo constituinte que conduziu ao texto constitucional atualmente vigente. $\mathrm{O}$ trabalho de deputados e deputadas que lutaram pelos direitos das mulheres e pela igualdade de gênero, especialmente, a igualdade entre os sexos, teve resultado expressivo no texto final promulgado em outubro de 1988 (PETER DA SILVA; GOMIDE, 2020, p. 28-44).

A norma mais importante está posta já no inciso I do art. $5^{\circ}$ da Constituição Republicana de 1988, preconizando, de forma clara e ressonantes, a igualdade entre homens e mulheres no Estado Democrático de Direito brasileiro:

Art. 50 Todos são iguais perante a lei, sem distinção de qualquer natureza, garantindo-se aos brasileiros e aos estrangeiros residentes no País a inviolabilidade do direito à vida, à liberdade, à igualdade, à segurança e à propriedade, nos termos seguintes:

I - homens e mulheres são iguais em direitos e obrigações, nos termos desta Constituição;

Também merecem destaque as normas constitucionais que reconheceram direitos fundamentais sociais, especialmente para as mulheres, atendendo às aspirações feministas relacionadas ao mercado de trabalho e à proteção à maternidade e à infância:

Art. 7o São direitos dos trabalhadores urbanos e rurais, além de outros que visem à melhoria de sua condição social:

$[\ldots]$

XVIII - licença à gestante, sem prejuízo do emprego e do salário, com a duração de cento e vinte dias;

XIX - licença-paternidade, nos termos fixados em lei;

$[\ldots]$

$\mathrm{XX}$ - proteção do mercado de trabalho da mulher, mediante incentivos específicos, nos termos da lei;

$[\ldots]$

XXX - proibição de diferença de salários, de exercício de funções e de critério de admissão por motivo de sexo, idade, cor ou estado civil; 
A Constituição de 1988 manteve norma constitucional que vem de longa data, a qual isenta o serviço militar obrigatório para as mulheres:

Art. 143. O serviço militar é obrigatório nos termos da lei.

$[\ldots]$

$\$ 2^{\circ}$ As mulheres e os eclesiásticos ficam isentos do serviço militar obrigatório em tempo de paz, sujeitos, porém, a outros encargos que a lei lhes atribuir.

No que diz respeito ao direito fundamental de propriedade, algumas normas constitucionais passaram a ser expressas para deixar evidente, na Constituição, a titularidade paritária entre homens e mulheres:

Art. 183. Aquele que possuir como sua área urbana de até duzentos e cinquenta metros quadrados, por cinco anos, ininterruptamente e sem oposição, utilizando-a para sua moradia ou de sua família, adquirir-lhe-á o domínio, desde que não seja proprietário de outro imóvel urbano ou rural.

$\$ 1^{\circ} \mathrm{O}$ título de domínio e a concessão de uso serão conferidos ao homem ou à mulher, ou a ambos, independentemente do estado civil.

$[\ldots]$

Art. 189. Os beneficiários da distribuição de imóveis rurais pela reforma agrária receberão títulos de domínio ou de concessão de uso, inegociáveis pelo prazo de dez anos.

Parágrafo único. O título de domínio e a concessão de uso serão conferidos ao homem ou à mulher, ou a ambos, independentemente do estado civil, nos termos e condições previstos em lei.

Não menos importante é considerar que, no capítulo relativo à família, a menção do constituinte originário foi inequívoca quanto à paridade de poderes familiares entre homens e mulheres, nas sociedades conjugais:

Art. 226. A família, base da sociedade, tem especial proteção do Estado. 
$\$ 3^{\circ}$ Para efeito da proteção do Estado, é reconhecida a união estável entre o homem e a mulher como entidade familiar, devendo a lei facilitar sua conversão em casamento.

$\$ 4^{\circ}$ Entende-se, também, como entidade familiar a comunidade formada por qualquer dos pais e seus descendentes.

$\$ 5^{\circ}$ Os direitos e deveres referentes à sociedade conjugal são exercidos igualmente pelo homem e pela mulher.

Por fim, não se pode deixar de registrar que a democracia paritária encontra na Constituição de 1988 aportes normativos potentes e inequívocos para a dogmática constitucional feminista. No Brasil, é a Constituição de 1988 que dá respaldo normativo explícito para que as decisões de poder estejam fundadas nos pressupostos de vedação à discriminação, como direito fundamental, e de igualdade de gênero, constituindo-se marca identitária e inexorável da Constituição de 1988.

A anotação de que não apenas as mulheres são diretamente beneficiárias das conquistas constituintes de 1987-1988, mas toda a comunidade nacional excluída (PETER DA SILVA; ROSA, 2019, p. 25), sustenta-se no fato de que o texto constitucional atualmente vigente no Brasil, em diversas oportunidades, foi claro e direto, ao proibir todos os tipos de discriminações odiosas. Algumas normas constitucionais podem comprovar o argumento:

Art. $3^{\circ}$ Constituem objetivos fundamentais da República Federativa do Brasil:

$[\ldots]$

IV - promover o bem de todos, sem preconceitos de origem, raça, sexo, cor, idade e quaisquer outras formas de discriminação.

$[\ldots]$

Art. $5^{\circ}$ Todos são iguais perante a lei, sem distinção de qualquer natureza, garantindo-se aos brasileiros e aos estrangeiros residentes no País a inviolabilidade do direito à vida, à liberdade, à igualdade, à segurança e à propriedade, nos termos seguintes:

I - homens e mulheres são iguais em direitos e obrigações, nos termos desta Constituição; 
XLI - a lei punirá qualquer discriminação atentatória dos direitos e liberdades fundamentais;

$[\ldots]$

Art. 7o São direitos dos trabalhadores urbanos e rurais, além de outros que visem à melhoria de sua condição social:

$[\ldots]$

XXXI - proibição de qualquer discriminação no tocante a salário e critérios de admissão do trabalhador portador de deficiência;

$[\ldots]$

Art. 227. É dever da família, da sociedade e do Estado assegurar à criança, ao adolescente e ao jovem, com absoluta prioridade, o direito à vida, à saúde, à alimentação, à educação, ao lazer, à profissionalização, à cultura, à dignidade, ao respeito, à liberdade e à convivência familiar e comunitária, além de colocá-los a salvo de toda forma de negligência, discriminação, exploração, violência, crueldade e opressão. (Redação dada pela Emenda Constitucional 65, de 2010)

$[\ldots]$

II - criação de programas de prevenção e atendimento especializado para as pessoas portadoras de deficiência física, sensorial ou mental, bem como de integração social do adolescente e do jovem portador de deficiência, mediante o treinamento para o trabalho e a convivência, e a facilitação do acesso aos bens e serviços coletivos, com a eliminação de obstáculos arquitetônicos e de todas as formas de discriminação. (Redação dada pela Emenda Constitucional 65, de 2010)

Verifica-se, portanto, que a dogmática constitucional feminista, no Brasil, tem no texto da Constituição de 1988 importante fonte de normas jurídicas vinculantes da mais alta hierarquia normativa, as quais devem ser consideradas, respeitadas e invocadas como instrumentos jurídicos potentes contra a odiosa discriminação e exclusão de quem quer que seja.

Mas não são apenas instrumentos de defesa, pois as normas constitucionais são também programas que obrigam os legisladores e agentes políticos do 
Executivo a fazerem, respectivamente, leis e políticas públicas que concretizem seus comandos com a máxima efetividade possível. Trata-se de um dever de legislar e uma obrigação de agir que, se não considerados e levados a sério, podem movimentar a jurisdição constitucional a atuar, quando provocada, em sede de controle de constitucionalidade da omissão.

\section{Premissas dogmático-jurisprudenciais do constitucionalismo feminista}

O Supremo Tribunal Federal, nos últimos dois anos, ou seja, 2019 e 2020, foi significativamente abundante ${ }^{10}$ no que diz respeito à jurisprudência constitucional feminista, considerando aqui como jurisprudência constitucional feminista aquela que se ocupa de temas que estão afetos aos direitos fundamentais das mulheres e ao universo temático, convencionalmente, considerado como de interesse do gênero feminino.

Serão apresentadas 13 decisões do Supremo Tribunal Federal julgadas e/ ou publicadas nos anos de 2019 e 2020. A escolha de tais decisões deu-se por pesquisa na base de dados disponível no sítio do Supremo Tribunal Federal, a partir da expressão "mulher", em somente decisões colegiadas do Pleno da Suprema Corte, excluindo-se as classes processuais habeas corpus, recurso em habeas corpus, mandado de segurança e reclamação.

Os precedentes serão apresentados por ordem cronológica de julgamento. É importante ressaltar que todos decorreram de ações do controle concentrado de constitucionalidade ou recursos extraordinários paradigmas de temas da repercussão geral.

Na Ação Direta de Inconstitucionalidade 6.039, ${ }^{11}$ julgada em 13 de março de 2019, em que se analisava a constitucionalidade de legislação do Rio de Janeiro que impunha a obrigatoriedade de que crianças e adolescentes do sexo feminino, vítimas de estupro, fossem examinadas por perito legista mulher, o Plenário da Suprema Corte afirmou que a lei impugnada estava “[...] em sintonia

\footnotetext{
10 O aumento dos julgamentos no Supremo Tribunal Federal ocorreu de uma forma geral, pois foram implementados mecanismos de julgamento virtual que potencializaram a capacidade quantitativa de julgamentos na Suprema Corte brasileira. Vide STF-Resolução no. 642/2019; STF-Emenda Regimental no. 53/2020; STF-Resolução nº. 669/2020; e STF-Emenda Regimental no. 54/2020.

${ }^{11}$ STF, ADI 6.039 MC, Tribunal Pleno, Rel. Min. Edson Fachin, j. 13 mar. 2019.
} 
com o direito fundamental à igualdade material (art. 5, I, da CRFB), que impõe especial proteção à mulher $\mathrm{e} o$ atendimento empático entre iguais, evitando-se a revitimização da criança ou adolescente, mulher, vítima de violência.." ${ }^{12}$

A decisão, tomada em sede de medida cautelar, ainda pendente de julgamento definitivo de mérito, foi no sentido de reconhecer a constitucionalidade da legislação estadual impugnada, porém, por razões de ordem prática e de urgência, deferir, parcialmente, a medida cautelar para dar interpretação conforme à norma estadual no sentido de reconhecer que as crianças e adolescentes deverão ser, obrigatória e prioritariamente, examinadas por legistas mulheres, desde que tal dever fundamental do poder público não importe retardamento ou prejuízo da diligência processual específica.

Nesse precedente, reafirmou-se o conteúdo material da proteção integral da criança e adolescente, bem como o mais amplo acesso à justiça, mas sem descurar da pergunta da mulher, ou seja, sem desconsiderar ou marginalizar o argumento de que a proteção integral da criança e adolescente mulher, especialmente no que diz respeito aos crimes contra a dignidade sexual, deve levar em conta a sua condição de gênero e as devidas e necessárias políticas públicas dela decorrentes.

Verifica-se, no precedente, a presença, algumas vezes implícita, da consideração de problemas íntimos e específicos das crianças e adolescentes do sexo feminino como questões constitucionais relevantes, a merecer o olhar e a proteção jurídica da Suprema Corte brasileira. Evidencia-se, assim, a influência da dogmática constitucional feminista nessa decisão.

$\mathrm{Na}$ Ação Direta de Inconstitucionalidade $3.774,{ }^{13}$ julgada em 23 de agosto de 2019, a discussão era sobre uma lei do Estado de Roraima que previa o limite etário máximo de 35 anos para o ingresso de homens e mulheres no serviço auxiliar voluntário do Corpo de Bombeiros e da Polícia Militar estaduais. A decisão da Segunda Turma da Suprema Corte foi no sentido de que não era proporcional e razoável estabelecer-se limite etário para o serviço voluntário de homens e mulheres nas instituições públicas em causa.

\footnotetext{
12 STF, ADI 6.039 MC, Tribunal Pleno, Rel. Min. Edson Fachin, j. 13 mar. 2019.

13 STF, ADI 3.774, Tribunal Pleno, Rel. Min. Roberto Barroso, j. 22 ago. 2019.
} 
Verifica-se, no discurso dos magistrados da Suprema Corte brasileira, que, exatamente por não ter havido qualquer menção expressa sobre a questão de gênero no debate constitucional travado, o resultado do julgamento observou, ainda que de forma implícita, o resguardo da igualdade de gênero, tal qual preconizado pela Constituição da República de 1988, em seu art. 5º, I. Importante lembrar, no ponto específico, que o Supremo Tribunal Federal já teve a oportunidade de declarar inconstitucional ato administrativo que perpetrava discriminação por gênero para ingresso em cargo público de instituições congêneres. ${ }^{14}$

Muitas vezes, os votos dos ministros e das ministras não expressam, de forma explícita, argumentos que demonstram as premissas dogmáticas do constitucionalismo feminista, especialmente aquelas propostas pela doutrina constitucional feminista. No entanto, o resultado do julgamento, por outros argumentos e fundamentos legislativos ou jurisprudenciais, resultam em uma proteção judicial efetiva dos direitos fundamentais das mulheres, como no caso.

Na Ação Direta de Inconstitucionalidade $5.971,{ }^{15}$ julgada em 13 de setembro de 2019, o pedido era de análise da constitucionalidade de lei distrital que instituiu diretrizes para a implementação da política pública de valorização da família, no âmbito distrital. O questionamento do partido político autor era de que o conceito de família, incorporado na legislação, era discriminatório em relação aos cidadãos e às cidadãs em uniões homoafetivas, de forma que a norma, no particular, deveria ser declarada inconstitucional.

A decisão da Suprema Corte, em sua composição plenária, foi no sentido de reconhecer a inconstitucionalidade do sentido discriminatório da norma distrital, enfatizando que:

[...] A única interpretação do artigo $2^{\circ}$, inciso I, que se mostra compatível com o texto constitucional é aquela que não exclua do conceito de entidade familiar, para fins de aplicação das políticas públicas previstas na Lei 6.160/2018, o reconhecimento de união estável contínua, pública e duradoura entre pessoas do mesmo sexo. ${ }^{16}$

\footnotetext{
14 STF, RE 528.684, Segunda Turma, Rel. Min. Gilmar Mendes, j. 3 set. 2013.

15 STF, ADI 5.971, Tribunal Pleno, Rel. Min. Alexandre de Moraes, j. 13 set. 2019.

${ }^{16}$ STF, ADI 5.971, Tribunal Pleno, Rel. Min. Alexandre de Moraes, j. 13 set. 2019.
} 
A decisão, tomada por unanimidade, confirmou a tese do antológico precedente firmado na Arguição de Descumprimento de Preceito Fundamental 132, ${ }^{17}$ segundo a qual "O sexo das pessoas, salvo disposição constitucional expressa ou implícita em sentido contrário, não se presta como fator de desigualação jurídica." Trata-se de uma importante confirmação do âmbito de proteção de diversas normas constitucionais expressas da Constituição da República de 1988, as quais são inequívocas quanto à coibição de todas as formas de discriminação no País.

No que diz respeito às premissas doutrinárias da dogmática constitucional feminista, é possível perceber, na decisão, consideração e respeito à interseccionalidade, ou seja, às teorias da diversidade na discussão constitucional posta. $\mathrm{O}$ precedente do Supremo Tribunal Federal tornou-se relevante, pela inequívoca premissa da interseccionalidade, uma das premissas doutrinárias da dogmática constitucional feminista.

A Ação Direta de Inconstitucionalidade $5.938^{18}$ foi julgada, em seu mérito, em 29 de maio de 2019, porém, em virtude de embargos de declaração, o julgamento só se concluiu em 11 de novembro do mesmo ano. Trata-se de precedente muito relevante para a jurisprudência constitucional feminista, pois cuida diretamente dos direitos fundamentais sociais das mulheres, especificamente aqueles relacionados ao mercado de trabalho e à proteção à maternidade e à infância, temas muito vinculados, culturalmente, ao universo feminino.

A discussão era sobre o ponto da reforma trabalhista que admitia a possibilidade de trabalhadoras grávidas e lactantes desempenharem atividades em locais insalubres, e o Plenário da Suprema Corte brasileira, em uma decisão inflexiva em relação aos demais pontos da reforma trabalhista, afirmou a inconstitucionalidade da norma, fazendo prevalecer a proteção à mulher, à maternidade e à infância, concretizando uma vontade constituinte expressamente registrada no texto constitucional de 1988 (PETER DA SILVA, 2019).

É preciso registrar que, nessa decisão, a proteção à mulher e à maternidade foi amplamente considerada e debatida pelos magistrados e pelas magistradas do Supremo Tribunal Federal, que deliberaram pela inconstitucionalidade da 
norma que admitia o trabalho da mulher gestante e lactante em ambiente insalubre, reafirmando que:

A proteção à maternidade e a integral proteção à criança são direitos irrenunciáveis e não podem ser afastados pelo desconhecimento, impossibilidade ou a própria negligência da gestante ou lactante em apresentar um atestado médico, sob pena de prejudicá-la e prejudicar o recém-nascido. ${ }^{19}$

No julgamento da Arguição de Descumprimento de Preceito Fundamental $460,{ }^{20}$ em 29 de junho de 2020, o Supremo Tribunal Federal enfrentou o tema da liberdade de cátedra, em face da concretização do princípio democrático no ensino fundamental, bem como dos temas relacionados à discriminação, especialmente relacionada a sexo, gênero e orientação sexual, no ambiente escolar.

A discussão sobre a constitucionalidade de legislação estadual que proibia, de forma genérica, a inclusão de determinados conteúdos nos currículos escolares, sob o argumento de que se tratava de conteúdo doutrinador ou proselitista, concluiu-se pelos votos dos magistrados e das magistradas do Supremo Tribunal Federal, em sessão plenária, no sentido da inconstitucionalidade da norma. Assim ficou registrada a compreensão constitucional do tema, na ementa do precedente:

[...] A vedação da abordagem dos temas de "gênero" e de "orientação sexual" no âmbito escolar viola os princípios da liberdade, enquanto pressuposto para a cidadania; da liberdade de ensinar e aprender; da valorização dos profissionais da educação escolar; da gestão democrática do ensino; do padrão de qualidade social do ensino; da livre manifestação do pensamento; e da livre expressão da atividade intelectual, artística, científica e de comunicação, independentemente de censura ou licença (artigos 1º, II e V; 5º, IV e IX; e 206, II, V, VI e VII, da Constituição Federal). 3. A cidadania, fundamento da República Federativa do Brasil assim como o pluralismo político, está consagrada na Constituição ao lado de objetivos fundamentais de construção de uma sociedade livre, justa e solidária e de combate à discriminação (artigos 1º, II e V; e 3o, I e IV, CRFB), sendo certo que o sistema político se funda na representação dos diversos setores da

\footnotetext{
19 STF, ADI 5.938, Tribunal Pleno, Rel. Min. Alexandre de Moraes, j. 29 maio 2019.

20 STF, ADPF 460, Tribunal Pleno, Rel. Min. Luiz Fux, j. 29 jun. 2020.
} 
sociedade, todos com liberdade para alcançar o poder por meio de processo político livre e democrático e com educação que os habilite a exercer essa liberdade. 4. A neutralidade ideológica ou política pretendida pelo legislador municipal, ao vedar a abordagem dos temas de "gênero" e "orientação sexual", esteriliza a participação social decorrente dos ensinamentos plurais adquiridos em âmbito escolar, mostrando-se não apenas inconstitucional, mas também incompatível com o nosso ordenamento jurídico. ${ }^{21}$

Importante registrar que este precedente se estabeleceu como paradigma para outras decisões que impugnavam normas com a mesma teleologia. Entre essas decisões, destaca-se um conjunto de ações julgadas, todas sob a relatoria do Ministro Roberto Barroso, na sessão virtual de 24 de agosto de 2020: i) ADPF 461, ii) ADI 5.580, iii) ADI 6.038, e iv) ADI 5.537. ${ }^{22}$

Importante aqui registrar a presença de mais de uma das premissas doutrinárias da dogmática constitucional feminista, no conjunto de decisões acima referenciadas, o que demonstra que há consciência e sensibilidade de alguns ministros e ministras da Suprema Corte brasileira para essa perspectiva. A consideração expressa, nos discursos constitucionais dos votos, acerca da igualdade, em geral, e da igualdade de gênero, em especial, sobre os direitos fundamentais numa perspectiva de políticas públicas, sobretudo, e, também, sobre as interseccionalidades, tão importantes para a doutrina constitucional feminista, indica que a dogmática constitucional faz eco na Suprema Corte brasileira.

No Recurso Extraordinário n. 576.967, ${ }^{23}$ julgado em 5 de agosto de 2020, o tema em discussão era a incidência da contribuição previdenciária patronal sobre o salário-maternidade. O Recurso Extraordinário n. 576.967 é o caso paradigma do Tema 72 da sistemática de repercussão geral do Supremo Tribunal Federal. O tema constitucional decidido pelo Plenário da Suprema Corte assim ficou registrado: "Inclusão do salário-maternidade na base de cálculo da Contribuição Previdenciária incidente sobre a remuneração”. ${ }^{24}$

\footnotetext{
${ }_{21}$ STF, ADPF 460, Tribunal Pleno, Rel. Min. Luiz Fux, j. 29 jun. 2020.

22 STF, ADPF 461, Tribunal Pleno, Rel. Min. Roberto Barroso, j. 21 ago. 2020; STF, ADI 5.580, Tribunal Pleno, Rel. Min. Roberto Barroso, j. 21 ago. 2020; STF, ADI 6.038, Tribunal Pleno, Rel. Min. Roberto Barroso, j. 21 ago. 2020 ; STF, ADI 5.537, Tribunal Pleno, Rel. Min. Roberto Barroso, j. 21 ago. 2020.

${ }_{23}$ STF, RE 576.967, Tribunal Pleno, Rel. Min. Roberto Barroso, j. 4 ago. 2020.

${ }^{24}$ STF, RE 576.967, Tribunal Pleno, Rel. Min. Roberto Barroso, j. 4 ago. 2020.
} 
O constitucionalismo feminista não exclui a análise dos problemas a partir da dogmática-jurídica clássica, entretanto, reforça, como expressamente constou dos votos de alguns magistrados do Supremo Tribunal Federal, que a existência de uma questão tributária e/ou previdenciária não impede que sejam debatidos pela Corte os efeitos da decisão para as mulheres. É a pergunta da mulher, que se coloca no ambiente da dogmática constitucional, tal qual exigido pelo art. $5^{\circ}$, I, da Constituição da República de 1988 (PETER DA SILVA; GOMIDE, 2020).

Esse precedente é um notório exemplo de que a utilização de barreiras processuais, bem como de discurso que desperdiça a oportunidade de discutir pautas que afetarão a vida das mulheres, pode ser superada pelas propostas da doutrina constitucional feminista, a qual propõe um deslocamento expresso dos problemas da esfera privada das mulheres para os espaços públicos também por elas habitado.

Mesmo sendo a discussão de fundo de outras áreas do direito, como a tributária, a proposta da dogmática constitucional feminista é que se analise o sistema como instrumento potencializador de justiça social, no caso, especialmente para as mulheres, que são as principais destinatárias da licença-maternidade. A decisão do Supremo Tribunal Federal assim registrou:

[...] 4. Esta Corte já definiu que as disposições constitucionais são legitimadoras de um tratamento diferenciado às mulheres desde que a norma instituidora amplie direitos fundamentais e atenda ao princípio da proporcionalidade na compensação das diferenças. No entanto, no presente caso, as normas impugnadas, ao imporem tributação que incide somente quando a trabalhadora é mulher e mãe cria obstáculo geral à contratação de mulheres, por questões exclusivamente biológicas, uma vez que torna a maternidade um ônus. Tal discriminação não encontra amparo na Constituição, que, ao contrário, estabelece isonomia entre homens e mulheres, bem como a proteção à maternidade, à família e à inclusão da mulher no mercado de trabalho. Inconstitucionalidade material dos referidos dispositivos. $^{25}$

${ }_{25}$ STF, RE 576.967, Tribunal Pleno, Rel. Min. Roberto Barroso, j. 4 ago. 2020. 
No julgamento do Recurso Extraordinário n. 639.138, ${ }^{26}$ que ocorreu em 18 de agosto de 2020, o âmbito de proteção da igualdade de gênero, nos termos em que preconizado pelo art. 5º, I, da Constituição da República de 1988, para fins de cálculo do valor do benefício de complementação de aposentadoria devida por entidade de previdência privada, a decisão do Plenário do Supremo Tribunal Federal, tomada por maioria, foi no sentido de que:

[...] 1. A isonomia formal, assegurada pelo art. 5o I, CRFB, exige tratamento equitativo entre homens e mulheres. Não impede, todavia, que sejam enunciados requisitos de idade e tempo de contribuição mais benéficos às mulheres, diante da necessidade de medidas de incentivo e de compensação não aplicáveis aos homens. 2. Incidência da eficácia horizontal dos direitos fundamentais, com prevalência das regras de igualdade material aos contratos de previdência complementar travados com entidade fechada. 3. Revela-se inconstitucional, por violação ao princípio da isonomia (art. $5^{\circ}$, I, da Constituição da República), cláusula de contrato de previdência complementar que, ao prever regras distintas entre homens e mulheres para cálculo e concessão de complementação de aposentadoria, estabelece valor inferior do benefício para as mulheres, tendo em conta o seu menor tempo de contribuição. 5. Recurso extraordinário conhecido e desprovido. ${ }^{27}$

A discussão trazida à apreciação da Suprema Corte brasileira, referente ao Tema 452 da sistemática da repercussão geral, foi resolvida aprovando-se a seguinte tese:

É inconstitucional, por violação ao princípio da isonomia (art. 5º I, da Constituição da República), cláusula de contrato de previdência complementar que, ao prever regras distintas entre homens e mulheres para cálculo e concessão de complementação de aposentadoria, estabelece valor inferior do benefício para as mulheres, tendo em conta o seu menor tempo de contribuição. ${ }^{28}$

Verifica-se que houve consideração e análise expressa, por parte da Suprema Corte brasileira, da questão da mulher, ou seja, das interferências, experiências e

\footnotetext{
${ }^{26}$ STF, RE 639.138, Tribunal Pleno, Rel. Min. Gilmar Mendes, Rel. p/acórdão Min. Edson Fachin, j. 18 ago. 2020.

27 STF, RE 639.138, Tribunal Pleno, Rel. Min. Gilmar Mendes, Rel. p/acórdão Min. Edson Fachin, j. 18 ago. 2020.

28 STF, RE 639.138, Tribunal Pleno, Rel. Min. Gilmar Mendes, Rel. p/acórdão Min. Edson Fachin, j. 18 ago. 2020.
} 
consequências da decisão para as vidas das mulheres, o que demonstra uma atenção do Supremo Tribunal Federal para a hermenêutica constitucional feminista.

Na Arguição de Descumprimento de Preceito Fundamental 509, ${ }^{29}$ julgada em 16 de setembro de 2020, a discussão era sobre a constitucionalidade, ou não, de lista de empregadores que tivessem submetido trabalhadores e trabalhadoras à condição análoga à de escravo. A Suprema Corte brasileira, em decisão que prestigiou a proteção contra a odiosa prática discriminatória, cruel e degradante dos cidadãos e cidadãs de cor de pele preta, assentou que:

\begin{abstract}
CADASTRO DE EMPREGADORES - NATUREZA DECLARATÓRIA - PRINCÍPIO DA PUBLICIDADE. Descabe enquadrar, como sancionador, cadastro de empregadores, cuja finalidade é o acesso à informação, mediante publicização de política de combate ao trabalho escravo, considerado resultado de procedimento administrativo de interesse público. ${ }^{30}$
\end{abstract}

Não é demais lembrar que o constitucionalismo feminista não se compromete apenas com a inclusão das mulheres na cidadania e dignidade humana, mas, também, com a inclusão de todos e todas que foram, institucional ou culturalmente, excluídos do acesso e gozo de seus direitos fundamentais, ao longo da história e consolidação do Estado Democrático de Direito. A presença da premissa da interseccionalidade é evidente nesse precedente do Supremo Tribunal Federal.

Destaca-se, assim, a observação feita por alguns magistrados da Suprema Corte brasileira no sentido de que a norma impugnada na presente ação, além de encontrar respaldo normativo interno na legislação infraconstitucional positiva brasileira, também "[...] integra todo um bloco normativo de regras constitucionais e internacionais, devidamente internalizadas ao ordenamento jurídico pátrio, em proteção ao trabalhador e ao combate à escravidão, razão pela qual não há violação à reserva legal”. ${ }^{31}$

\footnotetext{
29 STF, ADPF 509, Tribunal Pleno, Rel. Min. Marco Aurélio, j. 15 set. 2020.

30 STF, ADPF 509, Tribunal Pleno, Rel. Min. Marco Aurélio, j. 15 set. 2020.

31 STF, ADPF 509, Tribunal Pleno, Rel. Min. Marco Aurélio, j. 15 set. 2020.
} 
Uma importante observação que se deve fazer a partir da dogmática constitucional feminista é a de que as áreas dos direitos fundamentais não são isoladas, de modo que a necessária proteção contra discriminações em razão de raça, credo, origem étnica, classe social e hegemonia geopolítica ou cultural também faz parte dos temas afetos à dogmática constitucional feminista, especialmente no capítulo em que busca o estudo da concretização dos direitos fundamentais de todos e todas, incluídas as minorias, em geral, e as mulheres, em especial.

Por fim, o julgamento do Recurso Extraordinário 659.424, ${ }^{32}$ em 13 de outubro de 2020, discutiu a igualdade de gênero em face da imposição, apenas ao cônjuge varão, de comprovação de invalidez e dependência econômica para fins de concessão de pensão por morte de sua esposa/companheira servidora pública. Trata-se de precedente do Tema 457 da sistemática da repercussão geral, em que a Corte Suprema brasileira firmou a seguinte tese:

É inconstitucional, por transgressão ao princípio da isonomia entre homens e mulheres ( $\mathrm{CF}$, art. $\left.5^{\circ}, \mathrm{I}\right)$, a exigência de requisitos legais diferenciados para efeito de outorga de pensão por morte de ex-servidores públicos em relação a seus respectivos cônjuges ou companheiros/companheiras (CF, art. 201, V). ${ }^{33}$

É importante precedente da dogmática constitucional feminista porque permite a reflexão sobre a igualdade de gênero também como norma que beneficia os homens, ou seja, que reconhece a isonomia como uma via de mão dupla, que interpela os agentes públicos e políticos a construírem, por meio de seus atos e políticas públicas, uma verdadeira democracia paritária.

A exigência de comprovação de invalidez e dependência econômica apresenta-se assíncrona à realidade sociocultural dos tempos atuais, pois a condição da mulher e do homem como chefes de família tem sido alterada com o passar dos anos. O que se pode afirmar a partir desse precedente é que prevaleceu, nesse julgamento da Suprema Corte brasileira, a igualdade substancial de gênero, evidenciando a urgência da construção e do reconhecimento de uma dogmática constitucional feminista, instrumental jurídico para coibir e erradicar as situações inconstitucionais de desigualdade que ainda são persistentes na sociedade brasileira.

\footnotetext{
32 STF, RE 659.424, Tribunal Pleno, Rel. Min. Celso de Mello, j. 9 out. 2020.

${ }^{33}$ STF, RE 659.424, Tribunal Pleno, Rel. Min. Celso de Mello, j. 9 out. 2020.
} 


\section{Conclusão}

A dogmática constitucional, consolidada há mais de dois séculos, enfrenta desafios típicos do século 21, de modo que a proposta de uma releitura da dogmática constitucional clássica encontra respaldo na necessária inclusão de vozes, pensamentos e experiências que foram excluídas do movimento e processo originais que forjaram o Estado Democrático de Direito, desde o final do século 18 até nossos dias.

Por dogmática constitucional feminista compreendam-se os aportes instrumentais de doutrina especializada, das normas constitucionais positivadas e da jurisprudência constitucional colocados à disposição da comunidade jurídica para concretizar a igualdade de gênero, racial, de classes, étnica, cultural e geopolítica nas decisões de poder de uma nação.

O constitucionalismo feminista funda-se em pressupostos que interpelam os agentes públicos e políticos a atuarem, em seus respectivos âmbitos de competência, com uma visão mais plural, aberta e sustentável das políticas públicas de inclusão. A democracia paritária é fundamento estruturante do princípio da igualdade, que deixa sua ambiência meramente formal para também concretizar-se em sua versão material e substancial.

A proposta de igualdade material é dinâmica e inclusiva, impondo-se como princípio e meta da atuação dos agentes e órgãos detentores de competências públicas e privadas no seio da nação. A igualdade de gênero é o mais evidente pressuposto da dogmática constitucional feminista expresso na Constituição da República de 1988, no seu art. 5º, I.

Também se destaca, como premissa da dogmática constitucional feminista, a perspectiva objetiva dos direitos fundamentais, que reconhece a igualdade de gênero e proibição de todas as formas de discriminação como deveres fundamentais dos agentes políticos e públicos, compromissos institucionais das competências constitucionais que lhes são destinadas em virtude de seus mandatos e cargos. Nesse contexto, os direitos subjetivos assomam-se às políticas públicas que concretizam, em múltiplas perspectivas, os direitos fundamentais das mulheres e minorias de gênero.

As perspectivas comparativa e interseccional apresentam-se como exigências dogmáticas do constitucionalismo feminista porque, na atual quadratura do desenvolvimento das teorias constitucionais, não há como deixar de reconhecer 
a rede mundial de nações, plural e complexa, gerando seus influxos sobre os problemas constitucionais internos e externos em múltiplas direções. O deslocamento dos temas e interesses dos centros para as periferias mundiais responde às mesmas interpelações que essa dinâmica tem exigido para os estados nacionais.

É a diversidade, com suas teorias e experiências, que movimenta a dogmática constitucional feminista para uma postura hermenêutica da Constituição integral e inclusiva, que não nega a dogmática constitucional tradicional, mas a constrange com a exigência de resultados mais conformes com as Constituições e seus projetos constituintes.

O conjunto de normas constitucionais expressamente disponibilizado aos cidadãos e às cidadãs brasileiras como normas jurídicas vinculantes e de observância obrigatória é o argumento mais persuasivo da dogmática constitucional feminista. Não há como negar que a atual Constituição vigente no País, a começar pelo art. $5^{\circ}$, I, é fonte inexorável do direito constitucional feminista.

Por fim, já é possível colecionar, na jurisprudência mais recente do Supremo Tribunal Federal brasileiro, algumas dezenas de precedentes constitucionais que invocam discursos e argumentos constitucionais típicos da dogmática constitucional feminista. As ações do controle concentrado e recurso com repercussão geral registrados no presente trabalho demonstram que a jurisdição constitucional brasileira está aberta às premissas da dogmática constitucional feminista.

O motivo condutor da hermenêutica constitucional feminista é a pergunta da mulher, questionando e evidenciando as interferências, experiências e consequências das decisões constitucionais para a vida das mulheres e das minorias de gênero excluídas. Não se negam as conquistas do constitucionalismo clássico para as comunidades nacionais contemporâneas, mas se exige o seu progressivo resgate das promessas originais não cumpridas em relação às mulheres, aos negros, aos proletários e aos oprimidos.

Não há fórmulas prontas nem propostas fechadas para a empreitada de tecer, dialeticamente, as redes necessárias para a construção das condições de possibilidade de uma sociedade democrática paritária. Entretanto, os instrumentos de decisão disponibilizados pela dogmática constitucional feminista podem ajudar nesse desiderato. É preciso compromisso e engajamento com as políticas públicas e suas ações nesse caminho, que, não obstante seja íngreme e prenhe de desafios, presenteia a todos e todas que nele marcham com a esperança de uma comunidade nacional e internacional cada vez mais justa, igual, sustentável e feliz. 


\section{Referências}

BAINES, Beverley; BARAK-EREZ, Daphne; KAHANA, Tsvi. Feminist constitutionalism: global perspectives. New York: Cambridge University Press, 2012.

BARTLETT, Katherine T. Feminist legal methods. Harvard Law Review, Boston, n. 103, p. 829-888, 1990.

BEAUVOIR, Simone de. O segundo sexo. Rio de Janeiro: Nova Fronteira, 2000.

BORTOLUZZO, Adriana Bruscato; MATAVELLI, Ieda Rodrigues; MADALOZZO, Regina. Determinantes da distribuição da (des)igualdade de gênero entre os estados brasileiros. Estudos Econômicos, São Paulo, v. 46, n. 1, p. 161-188, Mar. 2016.

BRENNAN, Teresa. Interpretations of the flesh: Freud and femininity. London: Routledge, 1992.

BUTLER, Judith. Problemas de gênero: feminismo e subversão da identidade. Rio de Janeiro: Civilização Brasileira, 2003.

CANOTILHO, J. J. Gomes. Direito Constitucional e teoria da Constituição. 7. ed. Coimbra: Almedina, 2003.

CHUEIRI, Vera Karan de. Constituição radical: uma ideia e uma prática. Revista da Faculdade de Direito da UFPR, Curitiba, n. 58, p. 25-36, 2013. Disponível em: https://revistas.ufpr.br/direito/article/view/34863/21631. Acesso em: 26 abr. 2021.

COELHO, Margarete de Castro. O teto de cristal da democracia brasileira: abuso de poder nas eleições e violência política contra as mulheres. Belo Horizonte: Fórum, 2020.

CONNELL, Robert W.; MESSERSCHMIDT, James W. Masculinidade hegemônica: repensando o conceito. Revista Estudos Feministas, Florianópolis, v. 21, n. 1, p. 241-282, abr. 2013.

DALLARI, Dalmo de Abreu. Os direitos da mulher e da cidadã por Olimpia de Gouges. São Paulo: Saraiva, 2016. 
DWORKIN, Ronald. Uma questão de princípio. Tradução de Luís Carlos Borges. São Paulo: Martins Fontes, 2000.

FERRAZ JÚNIOR, Tércio Sampaio. Função social da dogmática jurídica. São Paulo: Editora Max Limonad, 1998.

FOUCAULT, Michel. A hermenêutica do sujeito. Tradução de Márcio Alves da Fonseca e Salma Tannus Muchail. São Paulo: Martins Fontes, 2006.

GARAY MONTANEZ, Nilda. Constitucionalismo feminista: evolucion de los derechos fundamentales en el constitucionalismo oficial. In: CORTS VALENCIANES. Igualdad y democracia: el genero como categoria de analisis jurídico. Valencia: Corts Valencianes, 2014, p. 265-280.

GONÇALVES, Eliane; PINTO, Joana Plaza. Reflexões e problemas da "transmissão" intergeracional no feminismo brasileiro. Cadernos Pagu, Campinas, n. 36, p. 25-46, jun. 2011.

GRESCHNER, Donna. Can Constitutions be for women too? In: CURRIE, Dawn; MACLEAN, B. (ed.). The administration of Justice. Saskatoon: Social Research Unit/University of Saskatchewan, 1986.

Häberle, Peter. El estado constitucional. Tradução de Hector Fix-Fierro. México: Universidad Nacional Autónoma de México, 2003.

HOOKS, Bell. O feminismo é para todo mundo. Tradução de Bhuvi Libanio, 13. ed. Rio de Janeiro: Rosa dos Tempos, 2020.

MACKINNON, Catharine A. Are women human?: and other international dialogues. Cambridge: Harvard University Press, 2006.

ONU MULHERES. Marco normativo para consolidar a democracia paritária, 2014. Trad. Prime Production, 2018. Disponível em: http://www.onumulheres. org.br/wp-content/uploads/2018/06/Marco-Normativo-Democracia-Paritaria_ FINAL.pdf. Acesso em: 12 dez. 2020. Especialistas (versão original): Line Bareiro, Erika Brockmann Quiroga, Blanca Olivia Peña Molina, Nielsen Pérez e María Inés Tula. 
PETER DA SILVA, Christine Oliveira. Constitucionalismo feminista ressoa no Supremo Tribunal Federal. Revista Consultor Jurídico, 28 dez. 2018. Disponível em: https://www.conjur.com.br/2018-dez-29/observatorio-constitucionalconstitucionalismo-feminista-ressoa-supremo-tribunal-federal?imprimir=1. Acesso em: 5 fev. 2020.

PETER DA SILVA, Christine Oliveira. Do ativismo judicial ao ativismo constitucional. Revista Brasileira de Políticas Públicas, Brasília, v. 5, n. 02, p. 63-87, 2015. Disponível em: https://www.publicacoes.uniceub.br/RBPP/ article/download/3094/pdf. Acesso em: 26 abr. 2021.

PETER DA SILVA, Christine Oliveira. STF protege gestantes e lactantes em face da reforma trabalhista. Revista Consultor Jurídico, 21 dez. 2019. Disponível em: https://www.conjur.com.br/2019-dez-21/observatorio-constitucional-stfprotege-gestantes-lactantes-face-reforma-trabalhista. Acesso em: 5 fev. 2020.

PETER DA SILVA, Christine Oliveira. Transjusfundamentalidade: diálogos transnacionais sobre direitos fundamentais. Curitiba: Editora CRV, 2014.

PETER DA SILVA, Christine Oliveira; GOMIDE, Carolina Freitas. Constitucionalistas constituintes: uma agenda para o Brasil. In: NOWAK, Bruna (org.). Constitucionalismo feminista: expressão das políticas públicas voltadas à igualdade de gênero. Salvador: JusPodium, 2020. v. 2, p. 17-55.

PETER DA SILVA, Christine Oliveira; GUINDANI, Talita Ferreira. Os direitos fundamentais das mulheres na Constituição de 1988. In: NOWAK, Bruna (org.). Constitucionalismo feminista. Salvador: JusPodivm, 2019. v. 1, p. 309-335.

PETER DA SILVA, Christine Oliveira; ROSA, Vanessa de Oliveira. Mulheres nas Constituições brasileiras. In: GODOY, Arnaldo; SILVA, Christine Peter da (org.), História Constitucional brasileira: estudos e reflexões. Brasília: Edições Uniceub, 2019.

PIOVESAN, Flavia. Ações afirmativas da perspectiva dos direitos humanos. Cadernos de Pesquisa, São Paulo, v. 35, n. 124, p. 43-55, jan./abr. 2005. Disponível em: https://www.scielo.br/pdf/cp/v35n124/a0435124.pdf. Acesso em: 26 abr. 2021.

RUBIO-MARIN, Ruth. Toward a feminist constitutional agenda. In: BAINES, Berverley.; RUBIO-MARIN, Ruth. (ed.). The gender of constitutional jurisprudence. Cambridge: Cambridge University Press, 2010. 
RUBIO-MARIN, Ruth; IRVING, Helen. Women as constitution-makers: case studies from the new democratic era. Cambridge: Cambridge University Press, 2019.

SILVA, Salete Maria da; WRIGHT, Sonia Jay. As mulheres e o novo Constitucionalismo: uma narrativa feminista sobre a experiência brasileira. Revista Brasileira de História do Direito, Minas Gerais, v. 1, n. 2, p. 170190, jul.-dez. 2015. ISSN: 2526-009X. Disponível em: https://www.indexlaw. org/index.php/historiadireito/article/view/666/pdf. Acesso em: 24 mar. 2020.

STANCHI, Kathryn M.; BERGER, Linda L.; CRAWFORD, Bridget J. (ed.). Feminist judgments: rewritten opinions of the United States Supreme Court. Cambridge: Cambridge University Press, 2016.

\section{Legislação citada}

BRASIL. [Constituição (1988)]. Constituição da República Federativa do Brasil de 1988. Brasília: Presidência da República, [2021]. Disponível em: http://www. planalto.gov.br/ccivil_03/constituicao/constituicao.htm. Acesso em: 26 abr. 2021.

BRASIL. Emenda Regimental no 53, de 18 de março de 2020, do Regimento Interno do Supremo Tribunal Federal. Altera dispositivo do Regimento Interno do Supremo Tribunal Federal para ampliar as hipóteses de julgamento por meio eletrônico e prever a realização de sustentação oral em ambiente virtual. Disponível em: http://www.stf.jus.br/ARQUIVO/NORMA/ EMENDAREGIMENTAL053-2020.PDF. Acesso em: 7 jul. 2021.

BRASIL. Emenda Regimental no 54, de $1^{\circ}$ de julho de 2020, do Regimento Interno do Supremo Tribunal Federal. Dá nova redação a dispositivos do Regimento Interno do Supremo Tribunal Federal, e acresce artigo. Disponível em: http://www.stf.jus.br/ARQUIVO/NORMA/EMENDAREGIMENTAL054-2020. PDF. Acesso em: 7 jul. 2021.

BRASIL. Resolução no 642, de 14 de junho de 2019, do Supremo Tribunal Federal. Dispõe sobre o julgamento de processos em lista nas sessões presenciais e virtuais do Supremo Tribunal Federal. Disponível em: http://www.stf.jus. br/ARQUIVO/NORMA/RESOLUCAO642-2019.PDF. Acesso em: 7 jul. 2021.

BRASIL. Resolução no 669, de 19 de março de 2020, do Supremo Tribunal Federal. Altera a Resolução no 642, de 14 de junho de 2019 e dá outras providências. Disponível em: http://www.stf.jus.br/ARQUIVO/NORMA/ RESOLUCAO669-2020.PDF. Acesso em: 7 jul. 2021. 


\section{Jurisprudência citada}

BRASIL. Supremo Tribunal Federal (Tribunal Pleno). Ação Direta de Inconstitucionalidade 3.774/RR. Relator: Min. Roberto Barroso, 22 de agosto de 2019. Disponível em: http://redir.stf.jus.br/paginadorpub/paginador. jsp?docTP=TP\&docID=750752286. Acesso em: 7 jul. 2021.

BRASIL. Supremo Tribunal Federal (Tribunal Pleno). Ação Direta de Inconstitucionalidade 5.537/AL. Relator: Min. Roberto Barroso, 21 de agosto de 2020. Disponível em: http://redir.stf.jus.br/paginadorpub/paginador. jsp?docTP=TP\&docID=753837203. Acesso em: 7 jul. 2021.

BRASIL. Supremo Tribunal Federal (Tribunal Pleno). Ação Direta de Inconstitucionalidade 5.580/AL. Relator: Min. Roberto Barroso, 21 de agosto de 2020. Disponível em: http://redir.stf.jus.br/paginadorpub/paginador. jsp?docTP=TP\&docID=754500974. Acesso em: 7 jul. 2021.

BRASIL. Supremo Tribunal Federal (Tribunal Pleno). Ação Direta de Inconstitucionalidade 5.938/DF. Relator: Min. Alexandre de Moraes, 29 de maio de 2019. Disponível em: http://redir.stf.jus.br/paginadorpub/paginador. jsp?docTP=TP\&docID=750927271. Acesso em: 7 jul. 2021.

BRASIL. Supremo Tribunal Federal (Tribunal Pleno). Ação Direta de Inconstitucionalidade 5.971/DF. Relator: Min. Alexandre de Moraes, 13 de setembro de 2019. Disponível em: http://redir.stf.jus.br/paginadorpub/paginador. jsp?docTP=TP\&docID=750960588. Acesso em: 7 jul. 2021.

BRASIL. Supremo Tribunal Federal (Tribunal Pleno). Ação Direta de Inconstitucionalidade 6.038/AL. Relator: Min. Roberto Barroso, 21 de agosto de 2020. Disponível em: http://redir.stf.jus.br/paginadorpub/paginador. jsp?docTP=TP\&docID=754500974. Acesso em: 7 jul. 2021.

BRASIL. Supremo Tribunal Federal (Tribunal Pleno). Arguição de Descumprimento de Preceito Fundamental 132/RJ. Relator: Min. Ayres Britto, 05 de maio de 2011. Disponível em: http://redir.stf.jus.br/paginadorpub/ paginador.jsp?docTP=AC\&docID=628633. Acesso em: 7 jul. 2021.

BRASIL. Supremo Tribunal Federal (Tribunal Pleno). Arguição de Descumprimento de Preceito Fundamental 460/PR. Relator: Min. Luiz Fux, 29 de junho de 2020. Disponível em: http://redir.stf.jus.br/paginadorpub/ paginador.jsp?docTP=TP\&docID=753445537. Acesso em: 7 jul. 2021. 
BRASIL. Supremo Tribunal Federal (Tribunal Pleno). Arguição de Descumprimento de Preceito Fundamental 461/PR. Relator: Min. Roberto Barroso, 21 de agosto de 2020. Disponível em: http://redir.stf.jus.br/paginadorpub/ paginador.jsp?docTP=TP\&docID=753886751. Acesso em: 7 jul. 2021.

BRASIL. Supremo Tribunal Federal (Tribunal Pleno). Arguição de Descumprimento de Preceito Fundamental 509/DF. Relator: Min. Marco Aurélio, 15 de setembro de 2020. Disponível em: http://redir.stf.jus.br/ paginadorpub/paginador.jsp?docTP=TP\&docID $=754002533$. Acesso em: 7 jul. 2021.

BRASIL. Supremo Tribunal Federal (Tribunal Pleno). Medida Cautelar na Ação Direta de Inconstitucionalidade 6.039/RJ. Relator: Min. Edson Fachin, 13 de março de 2019. Disponível em: http://redir.stf.jus.br/paginadorpub/paginador. jsp?docTP=TP\&docID=750311354. Acesso em: 7 jul. 2021.

BRASIL. Supremo Tribunal Federal (Segunda Turma). Recurso Extraordinário 528.684/MS. Relator: Min. Gilmar Mendes, 3 de setembro de 2013. Disponível em: http://redir.stf.jus.br/paginadorpub/paginador.jsp?docTP=TP\&docID=4927133. Acesso em: 7 jul. 2021.

BRASIL. Supremo Tribunal Federal (Tribunal Pleno). Recurso Extraordinário 576.967/PR. Relator: Min. Roberto Barroso, 4 de agosto de 2020. Disponível em: http://redir.stf.jus.br/paginadorpub/paginador.jsp?docTP=TP\&docID=754147264. Acesso em: 7 jul. 2021.

BRASIL. Supremo Tribunal Federal (Tribunal Pleno). Recurso Extraordinário 639.138/RS. Relator: Min. Gilmar Mendes. Redator para o acórdão: Min. Edson Fachin, 18 de agosto de 2020. Disponível em: http://redir.stf.jus.br/paginadorpub/ paginador.jsp?docTP=TP\&docID=754111259. Acesso em: 7 jul. 2021.

BRASIL. Supremo Tribunal Federal (Tribunal Pleno). Recurso Extraordinário 659.424/RS. Relator: Min. Celso de Mello, 9 de outubro de 2020. Disponível em: http://redir.stf.jus.br/paginadorpub/paginador. jsp?docTP=TP\&docID=754482386. Acesso em: 7 jul. 2021. 